\title{
Prve »javne« knjižnice v Veliki Britaniji
}

\author{
Izidor Janžekovič
}

Srednjeevropska univerza na Dunaju, Quellenstraße 51, 1100 Dunaj, Avstrija

https://orcid.org/0000-0002-6472-6308

izidor.janzekovic@gmail.com

Razprava obravnava prve »javne "knjižnicev Veliki Britaniji v zgodnjem novem veku (16. -19. stoletje) pred prvim pojavom pravih javnih knjižnic sredi 19. stoletja. Na podlagi kritičnega pregleda primarnih virov in sekundarne literature je predstavljen razvoj»javnih «knjižnic v zgodnjem novem veku. Avtor pokaže, kakšen je bil dostop javnosti do knjig v različnih tipih knjižnic, kdo je uporabljal te knjižnice in kakšno literaturo so brali v raznourstnih knjižnicah. Vbistuu je šlo za sočasen razvoj in vpliv: ni se najprej razvila dostopna literatura ali javna knjižnica, ampak je bil njun odnos vedno medsebojno pogojen in sorazmeren. Več poljudne literature je vodilo do večjega zanimanja za branje vjavnosti in več javnih knjižnic ter obratno. Čeprav so prve prave javne knjižnice stvar sredine 19. stoletja, je zainteresirana pismena javnost tudi v srednjem in zgodnjem novem veku imela dostop do knjižnic in knjig. Problem je bil »interes «večinsko nepismene javnosti pred industrijsko revolucijo, ko tudi zaradi subsistenčne ekonomije ni bilo dovolj časa za "prostočasne" aktivnosti.

Ključne besede: zgodovina knjižnic / javne knjižnice / Velika Britanija / 16.-19. stol. / župnijske knjižnice / knjižnice s članarino / izposojevalne knjižnice

\section{Uvod}

Naslov članka oziroma besedna zveza javna knjižnica je za čas pred 19. stoletjem delno zavajajoč. ${ }^{1}$ Drugi del besedne zveze je jasen, saj knjižnica praktično od svojih začetkov ni bistveno spreminjala svoje

${ }^{1}$ Za članek o knjižnicah sem raziskoval v več knjižnicah, med drugimi v Britanski knjižnici v Londonu, knjižnicah Bodleian v Oxfordu, Chetham v Manchestru in Western Park v Sheffieldu, kjer sem bil na raziskovalni misiji, ki jo je podprl Javni štipendijski, razvojni, invalidski in preživninski sklad RS. Pri prevodih mi je pomagal Angleško-slovenski slovar bibliotekarske terminologije Ivana Kaniča, a za več izrazov (še) ni gesla. Manjšo diskusijo glede težavnih terminov sem vodil s Kaničem in Dorotejo Emeršič, za kar se jima prijazno zahvaljujem. Za lektoriranje se zahvaljujem Tereziji Kekec. Za številne koristne pripombe in usmeritve se zahvaljujem še glavnemu uredniku revije Primerjalna književnost Marijanu Doviću in anonimnima recenzentoma. 
osrednje vloge: večja zbirka knjig ali kraj oziroma stavba, ki hrani to zbirko (Bray, Bibliothecae Americanae 2; Casson 3; Eberhart 1). Delno sporen je prvi del besedne zveze, to je javno, ki ga interpretiram na dva medsebojno neizključujoča si načina: 1 . kar je v lasti države oziroma javnosti, torej ne-zasebno; 2 . kar je javnosti odprto in dostopno. Samuel Johnson (1709-1784), avtor enega prvih angleških slovarjev $A$ Dictionary of the English Language, je podobno definiral pojem javno: »1. kar pripada državi, narodu ali skupnosti, ne zasebno; 2. odprto in splošno znano (publick)« (glej geslo v S. Johnson). Knjižnice, ki bi pripadale »državi, narodu ali skupnosti« so bile takrat redke, toda »odprte in splošno znane« knjižnice so bile na voljo zainteresirani javnosti veliko pred prvimi pravimi javnimi knjižnicami.

Kot javne torej razumem knjižnice, ki niso bile zasebne, a so bile pod določenimi pogoji na voljo zainteresirani pismeni javnosti. Slednja naj bi bila $\mathrm{v}$ protestantskem (britanskem) svetu v skladu z Lutrovim načelom sola scriptura precej visoka. Anglikanizem je sicer bolj sledil načelu prima scriptura, ki zraven Biblije upošteva še (krščansko) tradicijo, razum in izkustvo, medtem ko ima Biblija le "primat«. Vprašanje preučevanja pismenosti v predmoderni dobi je zapleteno in vključuje oceno pasivne ali bralne ter aktivne ali pisne pismenosti. Pri pričujočem članku me zanima predvsem pasivna ali bralna pismenost, ki pa jo je mnogo težje razpoznati. Čeprav vpliv religije ni bil zanemarljiv, so številni raziskovalci sklenili, da so socialni vzroki bili mnogo pomembnejši pri razvoju, zastoju in ponovnemu razvoju pismenosti v zgodnjenovoveški Angliji (Stone; Cressy; Stephens).

Razvoj knjižnic je v veliki meri odvisen od sočasnega razvoja književnosti. Vpliv knjižnic je bil medsebojen in sorazmeren vplivu književnosti na širšo družbo. Tehnologija določa knjižno produkcijo, distribucijo in zbiranje knjig, posledično tudi književnosti (Nethersole). Knjižnice so namreč bile posebni lokalni, kulturni in jezikovni prostori, to se pravi socialni prostori, ki so se hitro odzivali na spremembe v družbi. V bistvu je pri teh historičnih spremembah knjižnic od samostanskih do javnih treba razumeti tudi spremembe bralcev skozi stoletja. Če so bili $\mathrm{v}$ začetku 16. stoletja največji odjemalci duhovniki, menihi in aristokracija, pa se je dostop do knjig tekom zgodnjega novega veka bistveno "demokratiziral." V zgodnjem novem veku se je uveljavila in razširila metoda tihega zasebnega branja, čeprav je bilo glasno branje in širjenje (predvsem verskih) besedil med nepismenimi ljudmi vedno vseprisotno (Chartier 124-125; McLuhan; Saenger; Velagić).

Glavni viri za preučevanje zgodnjenovoveških knjižnic in književnosti so katalogi, ki so vse do 18 . stoletja še večinoma rokopisni, čeprav so 
jih veliko natisnili. Veliko teh katalogov je digitaliziranih in dostopnih na spletu. Pregledal sem tudi glavne pravne vire, kot so zakon o obveznem izvodu, in deklarativne vire, kot so statuti knjižnic. Spregledal nisem niti pamfletov in (avto)biografij glavnih pokroviteljev, ki so zasnovali gibanje za javne knjižnice. Trije ključni raziskovalci za zgodnjo zgodovino javnih knjižnic $\mathrm{v}$ anglosaškem svetu, na katere sem se naslonil tudi sam, so glavna dela napisali v šestdesetih letih 20. stoletja. Prvi je Thomas Kelly iz Liverpoola in njegova knjiga o zgodnjih javnih knjižnicah pred letom 1850. Drugi je Raymond Irwin iz Londona in dve njegovi zbirki prodornih esejev (Irwin, Heritage; The English). Tretji pa je Paul Kaufman iz Washingtona in njegova knjiga o knjižnicah ter njenih uporabnikih; posebej je koristen njegov članek v obsegu manjše knjige o javnih knjižnicah.

Kakšne so torej bile (javne) knjižnice v zgodnjem novem veku? Kakšen je bil dostop in interes javnosti? Kdo je dejansko uporabljal te knjižnice? Kaj so ljudje brali in kako se je razvijal dostop do književnosti? Članek začne na koncu preučevane dobe, saj se najprej na kratko loti pojava prvih "pravih" javnih knjižnic sredi 19. stoletja. Naposled sledi pregled treh glavnih oblik javnih knjižnic v širšem družbenem kontekstu, to so institucionalne knjižnice, podarjene oziroma podedovane knjižnice in knjižnice $s$ članarino, vključno $s$ številnimi podtipi. Zgodovino knjižnic preučim v odnosu do relevantne družbene, vzgojne, leposlovne in založniške zgodovine. Čeprav je mnogo knjižnic v zgodnjem novem veku bilo nominalno dostopnih za "javnost, " pa ta javnost ni bila pojmovana enako široko in inkluzivno kot danes.

\section{Prve "prave« javne knjižnice v 19. stoletju}

Sodobna javna knjižnica je ustanova, podprta z javnimi sredstvi, ki je pod določenimi pogoji odprta javnosti. Pravih javnih in splošnih izposojevalnih knjižnic Združeno kraljestvo Velike Britanije in (Severne) Irske (ZK) ne pozna do srede 19. stoletja. V ZK so leta 1850 sprejeli prvi odlok (Public Libraries Act, prim. Hamby in Najowitz; Minto 80-148), ki je vzpostavil knjižnice, podprte z davki (rate-supported libraries). Med drugim je ta odlok mestnim okrajem (borough) z več kot 10.000 prebivalci (kasneje znižano na 5.000 prebivalcev) dovolil pobiranje davka $v$ višini enega polpenija na funt, ${ }^{2}$ če skupnost to potrdi

\footnotetext{
${ }^{2}$ Funt je bil v skladu z dvanajstiškim sistemom takrat razdeljen na 240 penijev, tako da je to zneslo $1 / 480$ oz. 0,002\% funta. Združeno kraljestvo je na decimalni denarni sistem prešlo postopoma v letih 1968-1971.
} 
z dvotretjinsko večino. Denar so morali porabiti namensko za stavbo, opremo in osebje knjižnice, ne pa knjige! Morda se zdi bizarno, da proračun knjižnice ni namenjen nabavi knjig, a za knjige so predvideli, da jih bodo podarili premožni pokrovitelji, kakor so počeli dotlej in kar predstavim $\mathrm{v}$ članku.

Ta odlok je uveljavljal idejo javne knjižnice, ki se je takrat širila že nekaj generacij. V praksi je bil sicer odlok nezadosten, četudi so ga popravljali in dopolnjevali z novimi odloki ter amandmaji. Do leta 1867 je tako ta odlok izkoristilo le 27 mestnih okrajev in do leta 1886 je v ZK le 133 okrajev imelo prosto dostopne javne knjižnice. Zagovorniki odloka so poskusili promovirati idejo javnih knjižnic z izpostavljanjem nelaskavih primerjav s kontinentom, še posebej s Francijo, kjer »za te stvari skrbijo bolje« in imajo "zdaj več kot 1.000 javnih knjižnic" (Greenwood 1-2, 4, 14-15; seznam s statističnimi podatki na 389399). Vse to se je spremenilo leta 1887 , ko so ob praznovanju zlatega jubileja kraljice Viktorije samo v enem letu postavili kar 77 novih javnih knjižnic (Taylor, Whitfield in Barson 2-3).

Da pa bi prav razumeli sprejetje tega odloka leta 1850 , je treba razumeti širše družbene razmere $\mathrm{v}$ britanski družbi v prvi polovici 19. stoletja. Industrijska revolucija je spremenila vzorce dela, da so imeli delavci, vsaj glede na dojemanje sodobnikov, več prostega časa. Pravzaprav je izvor konceptov prostega časa in (kvalitetnega) družinskega časa za širšo populacijo povezan z industrijsko revolucijo (Hareven; Cunningham). ${ }^{3}$ Paternalistične izobražene in višje razrede je skrbelo, da bi delavci ta prosti čas dobro izkoristili oziroma, bolje rečeno, da se ne bi organizirali in upirali proti oblasti ter sistemu (McMenemy 24-26).

Poslanci so v tem času ustanovili več posebnih odborov s ciljem "razsvetlitve« javnosti, hkrati pa sprejeli več socialnih reform. Samo v zgodnjih 1830-ih so med drugim sprejeli volilno reformo, odlok o delu $\mathrm{v}$ tovarni in amandma k odloku o revežih. Družbeni aktivist Francis Place je leta 1834 na zaslišanju posebnega odbora o vzrokih pijanosti izjavil, da bi lahko "vzpostavitev župnijskih knjižnic in mestnih čitalnic ter ljudska predavanja odvrnila številne, ki obiskujejo javne hiše» (Buckingham 226). Poslanec iz Sheffielda in zagovornik vzdržnosti od alkohola oziroma abstinence James Buckingham je predlagal zakon o javnih ustanovah (Hansard 649-656), ki bi dovolil mestnim okrajem pobiranje davka za postavitev knjižnic in muzejev. Čeprav ni bil sprejet, je imel velik vpliv na poslanca Williama Ewarta in Josepha Brothertona,

${ }^{3}$ Seveda ima razlika med delom in nedelom ali prostim časom dolgo tradicijo vsaj od antike (negotium/otium), a je bil prosti čas večinsko namenjen le višjim slojem. 
ki sta deset let kasneje v parlamentu uspela z odlokom o muzejih. $S$ tem odlokom so mestni okraji že lahko vzpostavili knjižnice, a le če so bile fizično priključene muzejem.

Delo Ewarta in Brothertona je pripeljalo do posebnega parlamentarnega odbora, ki je pregledoval stanje javnih knjižnic. Pravzaprav je $\mathrm{k}$ temu bistveno pripomogel članek Edwarda Edwardsa (1812-1886), "očeta zgodovine knjižnic v Združenem kraljestvu“ (Passet 261) in asistenta v knjižnici Britanskega muzeja. ${ }^{4}$ Edwards je ocenil, da je bilo v Evropi takrat 383 večjih knjižnic, od tega v Združenem kraljestvu (takrat še s celotno Irsko in Malto!) le 28. Opravil je tudi zanimivo, a malce tendenciozno primerjavo med številom knjig in številom prebivalcev v mestih. Tudi tu se je Združeno kraljestvo odrezalo najslabše (43 knjig na 100 prebivalcev) v Evropi (Edwards, "A Statistical«), a je treba to pripisati še visoki urbanizaciji v Veliki Britaniji, $\mathrm{k}$ čemur je bistveno pripomogla tudi industrijska revolucija.

Edwards je želel vzbuditi nacionalna čustva s primerjavo glavnih javnih knjižnic na otoku proti tistim na kontinentu in v ZDA. Posebni parlamentarni odbor je izdal t.i. Ewartovo poročilo (Ewart Report), ki je po običaju dobilo ime po vodji parlamentarne preiskovalne skupine, čeprav je bil glavni raziskovalec prav Edwards. Ewart in Edwards sta trdila, da je trenutna ureditev za knjižnice $\mathrm{v}$ Združenem kraljestvu nezadostna in da je ureditev $\mathrm{v}$ drugih državah mnogo boljša. Tako so predlagali več izboljšav in leta 1850 posledično sprejeli zgoraj omenjeni odlok na čelu s financiranjem knjižnic. Edwards je za nagrado prevzel vodenje prve prave javne knjižnice, ki so jo po novem odloku odprli leta 1852 v Manchestru (slika 1). Že leto po nastopu je objavil knjižico treh poročil o knjižnici, izpostavil glavne napake odloka in predlagal popravke (Edwards, Three Reports; Munford). Edwards sicer ni bil politično najbolj spreten pri sodelovanju z lokalno skupnostjo, zato je že leta 1858 odstopil z mesta vodje knjižnice.

${ }^{4}$ Britanska knjižnica je bila sestavni del Britanskega muzeja od njegove ustanovitve leta 1753 . O pravi naravi institucije priča že nekdanji uradni naziv vodje Britanskega muzeja, ki je bil glavni knjižničar (Principal Librarian); danes seveda direktor. Uradna ločitev oziroma ustanovitev posebne Britanske knjižnice je prišla šele leta 1973, ko je vodja Britanskega muzeja tudi postal direktor. Toda še nadaljnjih četrt stoletja je preteklo, da je knjižnica dobila samostojno stavbo, in sicer na Euston Roadu, kamor so jo preselili leta 1997. 


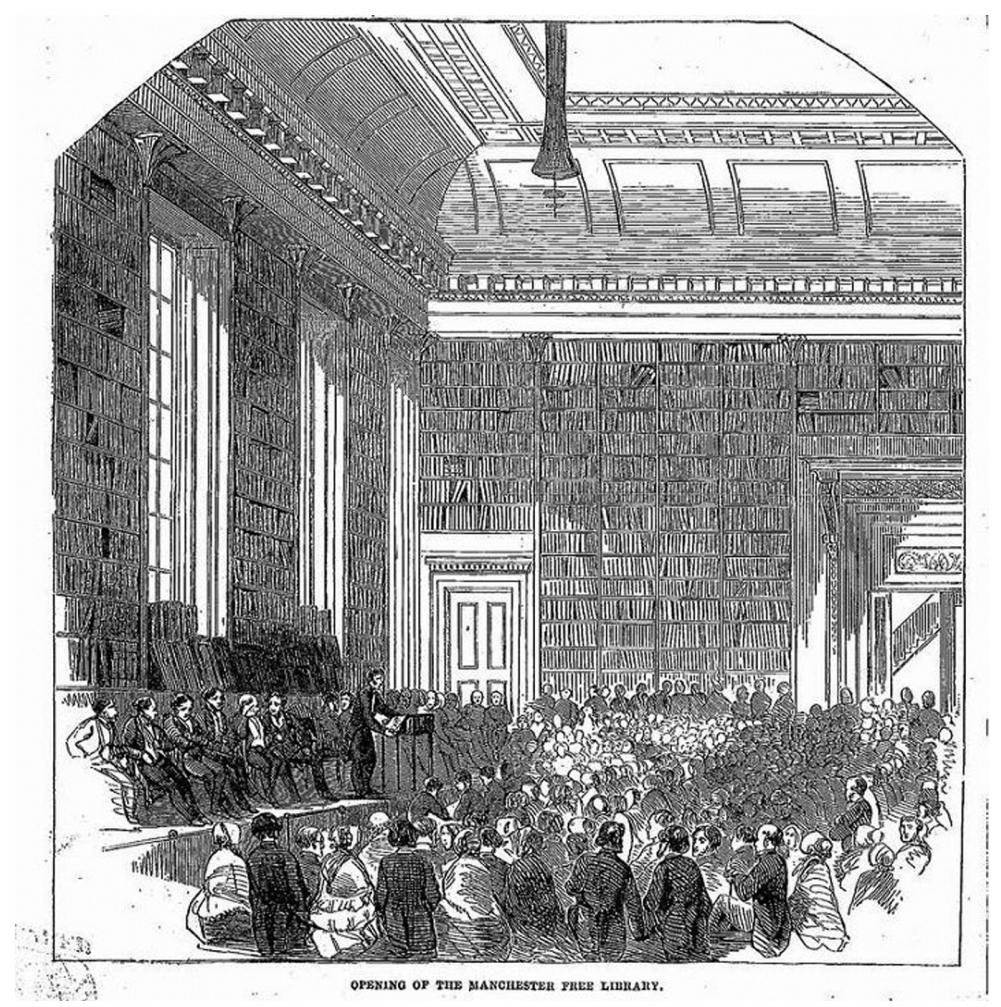

Slika 1: Odprtje prve prave javne knjižnice v Manchestru 5. septembra 1852 (Illustrated London News 4). Na odprtju je imel uvodni nagovor tudi pisatelj Charles Dickens, ki je izrazil »iskreno upanje, da bodo tako dostopne knjige prinesle užitek in izboljšavo v koče, sobe in kleti naših najrevnejših ljudi« (Credland 10).

Sredi 19. stoletja se začne tudi razmah »svetovne literature«(Weltliteratur), kot jo je poimenoval Goethe. Dostopnost književnosti se je povečala tudi zaradi večje založniške dejavnosti in prevodov. Bala Venkat Mani pripisuje ključno vlogo pri vzpostavljanju svetovne literature t.i. bibliomigranstvu. Knjižnica je imela pomembno vlogo v pridobivanju, distribuciji in kroženju zgodb med ljudmi, ki si knjig sami niso mogli privoščiti (Venkat Mani; Moretti). Pri tem so bile enako pomembne knjižnice in knjižne zbirke, ki so bile ključni mediji širjenja literarnih tekstov. V bistvu je šlo za sočasen razvoj in vpliv: ni se najprej razvila književnost ali knjižnica, ampak je bil njun odnos vedno medsebojno pogojen in sorazmeren. Več je bilo knjig in literature, več je bilo knjižnic in bralcev; enako seveda velja v obratno smer. 


\section{"Javne« knjižnice v zgodnjem novem veku}

Preden se lotim pregleda treh glavnih oblik javnih knjižnic v širšem družbenem kontekstu, to so institucionalne knjižnice, podarjene oziroma podedovane knjižnice in knjižnice s članarino, vključno s številnimi podtipi, najprej knjižnice razdelim na zasebne in javne. Ta razdelitev ima svoje ovire, ker je običajno zasebna knjižnica slejkoprej prišla v »javne roke«, običajno z darom, oporoko ali dedovanjem. Zasebne knjižnice v domovih, ki jih je uporabljala lokalna skupnost, so ponekod bile dostopne in imele velik pomen za javnost (Fehrenbach). Razumljivo je bila večina takih knjižnic lokalnih in individualnih brez enotne usmeritve ali ureditve. $V$ tem pregledu jih podrobneje ne opišem, a je dobro razumeti širši kontekst, saj so imele velik vpliv na razvoj javnih knjižnic.

Pred renesanso v VB praktično ni bilo zasebnih zbirk, saj so bile skoraj vse knjižnice v samostanih. Obstajajo izjeme, ki potrjujejo pravilo, npr. knjižnica durhamskega škofa Richarda de Buryja (1287-1345). Tik pred smrtjo je spisal knjigo dvajset kratkih esejev ali poglavij v latinščini in skoval naslov s pomočjo grščine: Philobiblon (Ljubezen do knjig), ki so ga široko brali še v 15. stoletju. Gre za eno prvih knjižničarskih del, ki med drugim zagovarja prost dostop do knjig za učenjake in uporabo kataloga (Bury xix). Prav tako je želel vpeljati izposojo knjig med študente in občasno prosto dostopne knjige. Takrat in še dolgo zatem so namreč prevladovale referenčne knjižnice, kjer je uporabnik knjige lahko referiral oziroma bral samo v knjižnicah. Bury je želel podariti zbirko svoji univerzi v Oxfordu, a je umrl globoko zadolžen, zato so njegove knjige zasegli in razprodali (Brown-Syed).

Še en znameniti zasebni zbiralec knjig je bil gloucesterski vojvoda Humphrey (1390-1447), samozvani najmlajši »sin [Henrika IV], brat [Henrika V] in stric [Henrika VI] kraljev«. Med drugim je naročil številne prevode klasičnih del iz grščine v latinščino. Ob smrti je zapustil rokopise Oxfordu, kjer so za to zbirko zgradili posebno čitalnico (Duke Humfrey's Library). Čitalnica je še danes del (javne) knjižnice Bodleian (vrh slike 2), ohranjeni pa so le trije od 281 srednjeveških rokopisov vojvode Humphreyja (Vickers). V teh primerih "zasebnih« knjižnic je vidna izrazita dolga tradicija oziroma longue durée gibanja za "javne» knjižnice, kar med drugim dokazujejo številni katalogi in predaje knjižnih zbirk določeni instituciji po smrti. 


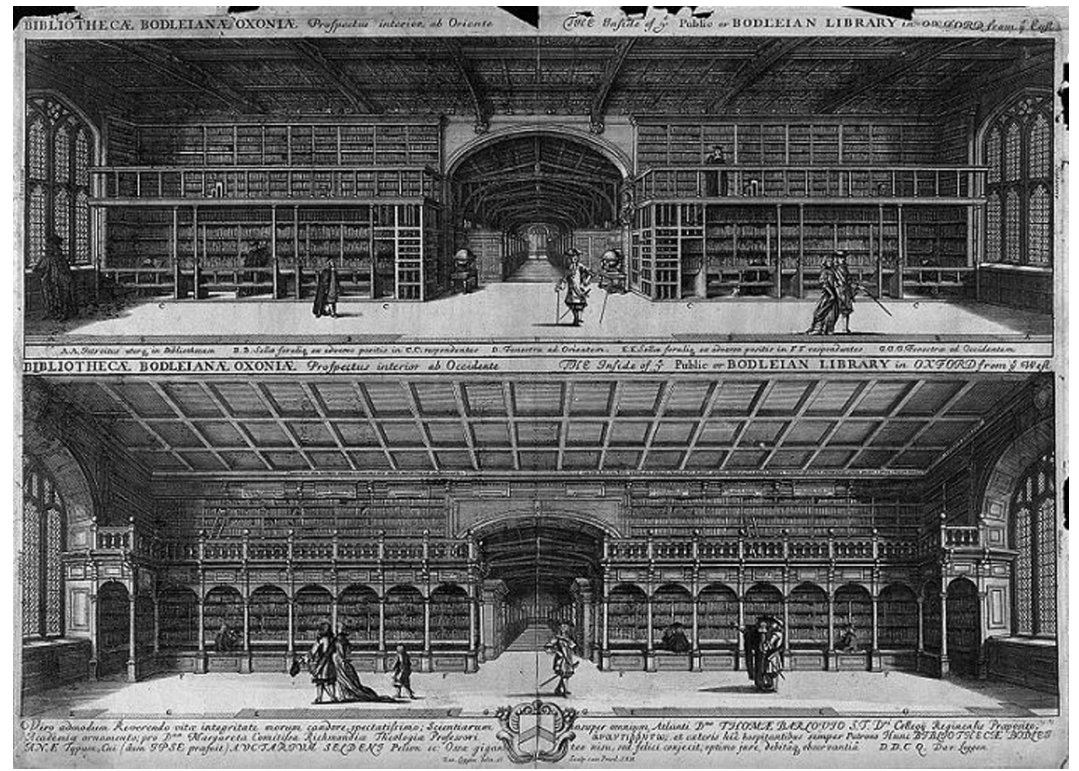

Slika 2: Obnovljena knjižnica vojvode Humphreyja v Oxfordu (Loggan). V letih 1610-1612 so tukaj v Angliji prvič v stene vzidali knjižne omare. Knjige na zgornjih policah niso bile pritrjene $\mathrm{z}$ verigami (Wood, The History). V večji meri je knjižnica ohranila to podobo vse do danes in je služila kot navdih za Prepovedani oddelek knjižnice na Bradavičarki v priljubljenih romanih in filmih o Harryju Potterju.

Institucionalne knjižnice so bile na meji med zasebnim in javnim. Te knjižnice so bile običajno del ustanove, ki je primarno služila drugim namenom, kot so samostani, katedrale in univerze. Tako je govora o samostanskih, katedralnih in univerzitetnih knjižnicah, ki so bile v tem času prezenčne oziroma referenčne knjižnice. Praktično vse knjižnice v srednjem veku so bile v samostanih, kjer so jih zelo cenili. Tako je Geoffrey iz samostana svete Barbare v Normandiji, ki je bila takrat tesno povezana z Anglijo, leta 1170 zapisal: »Samostan brez knjižnice je kot utrdba brez orožarne." (Neuhofer 12, 50) V latinskem izvirniku je stavek neprimerno močnejši: "Claustrum sine armario est quasi castrum sine armamentario." Tudi opat v Ecovem romanu Ime rože je rekel protagonistu frančiškanu Viljemu: "Monasterium sine libris est sicut civitas sine opibus, castrum sine numeris, coquina sine supellectili, mensa sine cibis, hortus sine herbis, pratum sine floribus, arbor sine foliis. ${ }^{5}$ (Eco 39)

${ }^{5}$ Samostan brez knjig je kot mesto brez (vojaških) sredstev, utrdba brez vojakov, kuhinja brez pripomočkov, miza brez hrane, vrt brez zelišč, travnik brez cvetov in drevo brez listov. 
Takrat sicer ni bilo posebnih prostorov za hranjenje knjig in so jih običajno imeli v skrinjah ali omarah. Večji samostani v Angliji so postopoma zgradili večje "sobe s knjigami" (book rooms), ki so bile ločene od skriptorijev, a prve šele v poznem srednjem veku. Načeloma so bile dostopne za javnost na vpogled, a je bila laična javnost $\mathrm{v}$ tem času večinoma nepismena in nezainteresirana. Jedro teh referenčnih knjižnic so bile obredne in teološke knjige, nekaj pa je bilo pedagoških, pravnih, astronomskih oziroma astroloških, kuharskih in medicinskih knjig. Zbirke so rasle na tri načine: $s$ prepisovanjem, $\mathrm{z}$ občasnimi nakupi in z darovanjem. Knjige so se posojale znotraj samostana, le redko navzven (Putnam).

V letih 1533-1553 so v Angliji zaradi reformacije zaprli preko 800 katoliških samostanov, knjige pa večinoma razprodali, v redkih primerih požgali. Uničenje seveda ni bilo povsod enako "temeljito". V knjižnici stolnega priorja v Durhamu je ostalo $560 \mathrm{knjig}$, iz velike knjižnice opatije v Leicestru pa le 15 (Youings). Še pred tem zatrtjem je kralj Henrik VIII. leta 1533 pooblastil pregled knjižnic vseh verskih ustanov. Zadolžil je antikvarja, »očeta angleške lokalne zgodovine in bibliografije«, Johna Lelanda (1503-1552) (Chandler xxi). Tako je v naslednjih letih potoval po samostanih in sestavljal sezname pomembnih ter neobičajnih knjig. Ker je svoja potovanja začel vestno beležiti še pred zatrtjem samostanov, je neprecenljiv vir za angleško lokalno zgodovino in srednjeveške samostanske knjižnice (Carley).

Kmalu po sprejetju prvega odloka o zatrtju cerkvenih ustanov leta 1536 je Leland že tožil nad uničenjem samostanskih knjižnic in v pismu prosil glavnega ministra Thomasa Cromwella za pomoč pri reševanju knjig. Pri tem je Leland podobno kot Edwards dobrih tristo let kasneje igral na nacionalna čustva in napisal: "Nemci so opazili našo malomarnost in zapostavljanje ter dnevno pošiljajo mlade učenjake, da uničujejo knjige, jih odtrgajo iz knjižnic, se vrnejo domov in jih razstavijo kot znamenitosti v lastni državi.« (nav. v Wood, Athenae 198; Shrank 100) Drugi sočasni opazovalec John Bale je pripomnil, da so nekateri plenilci "kupili«samostane, da bi jih »oropali njihovih knjig» (Piesse 60-61).

Leland je sestavil sezname pomembnih knjig in se zavzel za njihovo ohranitev (Leland). Kralju je svetoval, da bi s tem "plenom" obogatil staro Kraljevo knjižnico (Royal Library), ki jo je začel zbirati njegov predhodnik Edvard IV. (vladal 1461-1470 in 1471-1483). Prvi rokopisni katalog te zbirke je nastal leta 1604. Danes je v zbirki 2034 rokopisov, ki jih je Britanska knjižnica digitalizirala. Leland ni bil edini pri teh pozivih, saj je John Dee apeliral na »krvavo " kraljico Marijo v letih 1555 in 1556, da bi rešili najstarejše angleške rokopise. Izpostavil je priložnost za oblikovanje odlične knjižnice z nizkimi stroški, kar je na koncu storil sam. 
Katedralne knjižnice so delile usodo samostanov, a so se škofije lažje preoblikovale v anglikanske ustanove, zato je bilo tem knjižnicam prizanešeno. Poročilo kraljeve komisije iz leta 1854 je ocenilo, da imata katedrali v Durhamu in Manchestru vsaka okrog 11.000 zvezkov, katedrali v Yorku in Londonu po 8.000, večina ostalih katedralnih knjižnic je imela med 2.000 in 5.000 zvezkov (glej Report of Her Majesty's Commissioners). Knjige so bile pretežno teološke po tematiki, nekaj pa zgodovinskih, klasičnih in topografskih del. V tem času so knjige začeli postavljati na police in pritrjevati z verigami, kar so določene knjižnice uporabljale še v 18. stoletju (Kelly, Books 58-67; slika 3).

Knjižnice katedral so bile manjše od samostanskih, a bolj dostopne zaradi geografske lokacije v mestih. Pri dostopnosti je sicer treba biti previden. Te referenčne knjižnice namreč niso imele knjižničarjev, zato so bile običajno odprte ob najavi: knjižnici katedral v Durhamu in Yorku sta bili kot izjemi odprti pet dni na teden. V Durhamu so med letoma 1711 in 1801 "postregli« 6.364 bralcem. Kaufman je ugotovil po pregledu računovodskih knjig in registrov izposoj, da so laiki sicer redko uporabljali katedralne knjižnice (le 15\% vseh uporabnikov). Večina uporabe je bila notranja, omejena na duhovnike in kanonike (Kaufman, "Reading «). Zanimivo, da jih zainteresirana javnost iz različnih razlogov ni pretirano uporabljala niti tam, kjer ni bilo alternativ; verjetno zaradi relativno malih zbirk in omejenega odpiralnega časa.

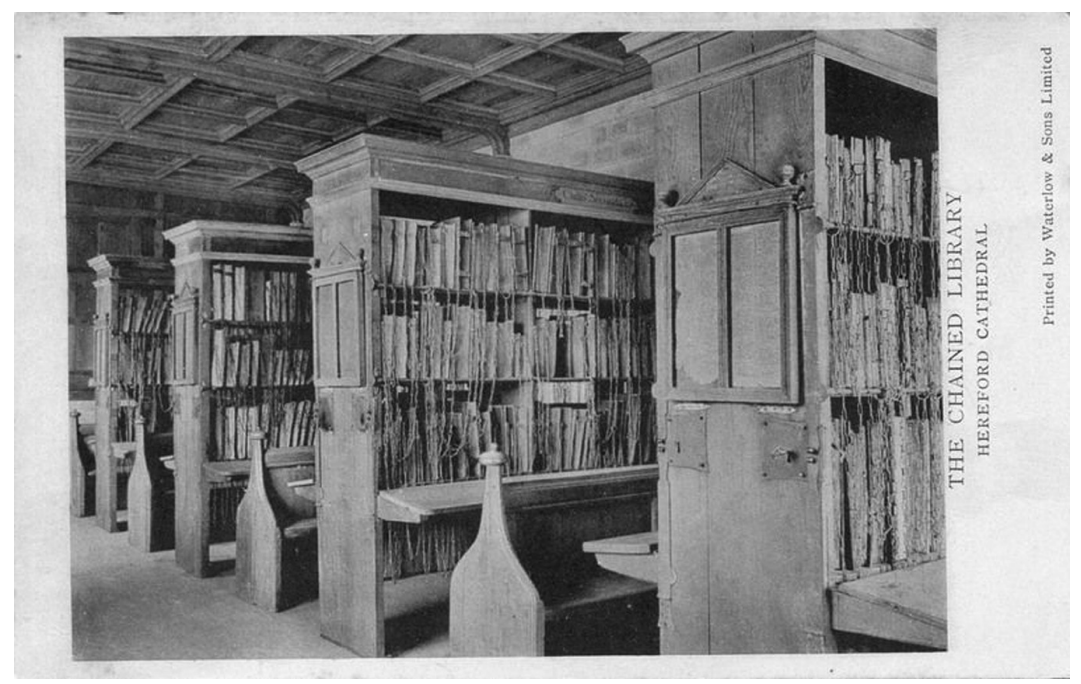

Slika 3: Katedralna knjižnica v Herefordu na razglednici iz 1950-ih. Klopi in bralne police, ki so se razvile iz srednjeveške katedre, so iz leta 1611 in so jih kopirali iz zgoraj omenjene knjižnice vojvode Humphreyja v Oxfordu. Knjige stojijo s sprednjim delom navzven in so pritrjene z verigo. 
Najpomembnejša univerzitetna knjižnica je v Oxfordu in je druga največja knjižnica v ZK (za Britansko knjižnico). V univerzitetni knjižnici so že v 14. stoletju dobili prvo zbirko knjig od worcesterskega škofa Thomasa Cobhama in jo leta 1367 postavili v cerkev svete Marije; leta 1410 so dodali bralne mize. Sredi 15. stoletja so dedovali Humphreyjevo zbirko in ji zgradili posebno stavbo. Vse zbirke je doletel tragičen konec z reformacijo, ko so komisarji Edvarda VI. "stare« katoliške knjige zaplenili, pohištvo pa prodali. Do leta 1556 je bila knjižnica praktično prazna, saj se je univerza odločila prodati še pohištvo. Skoraj petdeset let univerza ni imela prave knjižnice, čeprav so številne knjižnice kolidžev cvetele (Craster).

Toda to je bil prikrit blagoslov. Ko se je namreč diplomat Sir Thomas Bodley (1545-1613) konec 16. stol. upokojil in vrnil v Oxford, je sklenil obnoviti "uničeno in zapuščeno" knjižnico; po njem imenovana knjižnica Bodleian je vrata odprla leta 1602. Ključna odločitev je bila zaposlitev sposobnega knjižničarja Thomasa Jamesa. Slednji je izdal v latinščini spisan prvi katalog "javne knjižnice" (bibliotheca publica), v katerem so bile knjige razvrščene po abecednem redu po štirih fakultetah: teologija, medicina, pravo, filozofija oziroma "umetnosti« (libri artium); knjige so bile nadalje organizirane po velikosti (folio, quarto, octavo) (T. James, Catalogus librorum; Catalogus universalis; Carpenter 108-111; Jayne; Norris). Oxfordski katalog je le nekaj let zaostajal za prvim tiskanim katalogom institucionalne knjižnice na svetu iz Leidna (Bertius); vse do 18. stoletja so sicer prevladovali rokopisni katalogi knjižnic (Molino 306).

Še bistvenejša pa je bila Bodleyjeva sposobnost pridobivanja knjig. Bodley je leta 1610 sklenil dogovor s Papirniško družbo (Stationers' Company, tj. družba tiskarjev in založnikov; prim. Myers in Harris) za prostovoljne predaje knjig, $s$ čimer je postavil zametek za kasnejši zakon o obveznem izvodu. Hkrati je zgradil podaljšek knjižnični zgradbi in priskrbel primerno pohištvo. Kasneje je knjižnica rasla počasneje, a že do angleške državljanske vojne (1642-1651) je postala ena najboljših knjižnic v Evropi (Clapinson). Francis Bacon je v pismu Bodleyju leta 1605 časom primerno ocenil njegovo vlogo pri postavitvi knjižnice $\mathrm{v}$ Oxfordu, saj naj bi »ustvaril (Noetovo) barko [Ark], da bi rešil znanje pred potopom« (Bacon 253).

Skoraj diametralno nasprotno zgodbo ima univerzitetna knjižnica v Cambridgeu. Univerza je ubežala največjim pregonom sredi 16. stoletja, dobila je celo veliko samostanskih knjig ter darov zbirk, a po drugi strani ni imela takega pokrovitelja, kot je bil kasneje Bodley v Oxfordu (Jayne 42; Fox; Oates). Če je Oxford svojo knjižnico cenil in negoval, 
bi naj Cambridge knjižnico zanemarjal. Sočasni zgodovinar Thomas Fuller je celo obsodil knjižničarje v Cambridgeu, da bi morali tamkajšnje "hranilce knjig" (Library Keepers) preimenovati v »izgubljevalce knjig" (Library Loosers) (Fuller 79).

Podarjene oziroma podedovane knjižnice (endowed libraries) so bile vzpostavljene $\mathrm{z}$ darom pokrovitelja ali skupine pokroviteljev. Najpogostejši manifestaciji te vrste sta bili župnijska knjižnica in mestna knjižnica. Tako bi jih lahko pripeli institucionalnim, a je bil prispevek pokrovitelja bistven že za njihov nastanek, ne samo obstoj in kasnejšo rast. Pogosto so služile večjemu območju, kot ga je obsegala župnija ali mesto. Edward Edwards je pravilno ocenil, da je veliko najboljših knjižnic dolgovalo svoje začetke trudu župnikov (Edwards, Memoirs 556-557). Zuupnijske knjižnice za klerike so bile običajno relativno majhne z okrog 70 knjigami (izposojevalne lahko 200 knjig), ki so jih imeli v skrinji s policami in je služila še kot predalnik (slika 4). Za časa Elizabete I. so ustanovili le pet župnijskih knjižnic, nekaj več v 17. stoletju, a do leta 1700 jih je bilo manj kot 100 in še to večina v mestih (Kelly, Early). Malokatera župnija si je namreč lahko privoščila knjižnico, kar sta pa skoraj lastnoročno spremenila dva goreča pastorja.

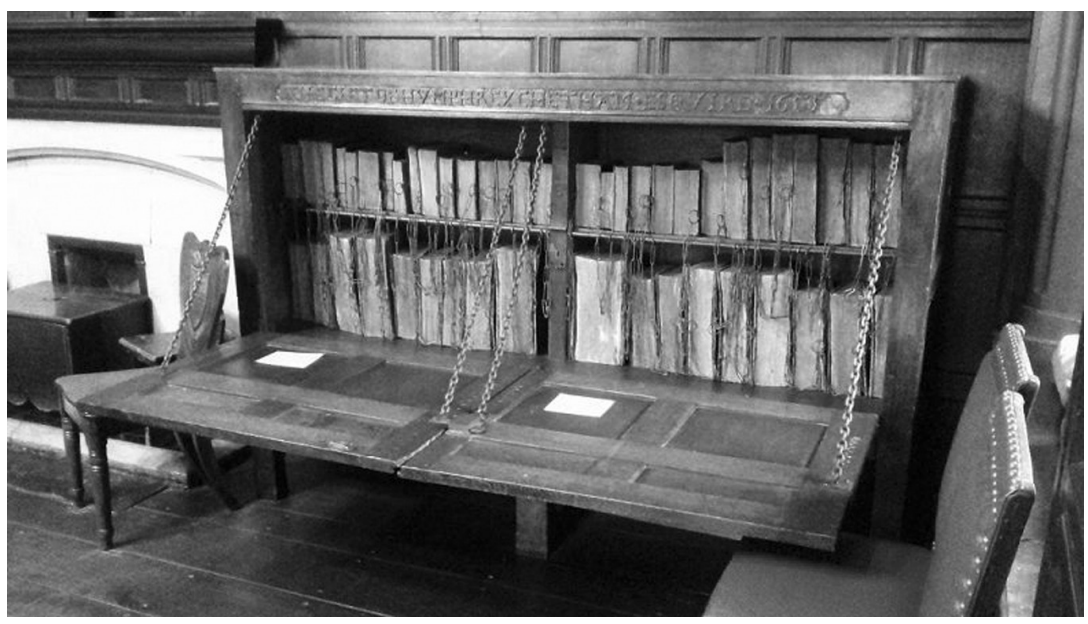

Slika 4: Župnijska knjižnica iz kapele v Gortonu; trenutno v Chethamovi knjižnici v Manchestru (Foto Izidor Janžekovič 2017). Tako je izgledala tipična preprosta župnijska knjižnica. Imela je 55 knjig večinoma nabožne narave in je stala 33 funtov. Sredstva zanjo je v oporoki zapustil trgovec Humphrey Chetham, čigar ime je izrezljano na vrhu. 
Prvi je bil Thomas Bray (1656/58-1730), ki ga je londonski škof leta 1696 poslal v »katoliški« Maryland, da bi tam organiziral anglikansko cerkev. Bray je sklenil, da bo vzpostavil knjižnice, ki bi pritegnile mlade izobražene duhovnike, kakor je kasneje pojasnil v svoji avtobiografiji (Bray, Brief Account, Steiner). Napisal je Predloge, kjer se je zavzel za knjižnico v vsaki ameriški župniji. Te knjižnice bi bile striktno referenčne, nahajale pa bi se v večji sobi župnije, kjer bi jo lahko referiral samo pastor (Bray, Proposals). Strah pred krajami knjig je bil vseprisoten, zato so sprejeli več ukrepov: pritrjevanja knjig z verigami, zaklepanje, znotraj knjig so vpisali, iz katere župnije je določena knjiga, da bi jo lahko izsledili itd.

$S$ temi predlogi je vzbudil navdušenje in začel zbirati knjige ter denar. Leta 1697 je spisal članek, ki je razširil shemo teh knjižnic na Anglijo in Wales. Bray je ocenil, da je okrog 2000 župnij, ki si komaj privoščijo kakšno knjigo. $\mathrm{V}$ tem delu je tudi sestavil šest strani dolg katalog knjig primernih za takšne knjižnice. Med 63 predlogi prevladujeta teologija (36 knjig) in cerkvena zgodovina (6 knjig), a upošteva vse "žanre, « tudi geografijo in potopise (11 knjig), splošno zgodovino (4 knjige), klasične antične avtorje (4 knjige), medicino (1 knjiga) in vrtnarstvo (1 knjiga) (Bray, An Essay; McCulloch 51). Je pa prilagodil svoj predlog in vključil še izobraženo in aristokratsko lokalno prebivalstvo, ki bi lahko uporabljalo knjige ter si jih sposodilo na dom (lending libraries) (Bray, Bibliothecae Americanae; Bibliotheca Parochialis).

Brayjevih "anglikanskih» knjižnic niso ustanavljali na Škotskem, kjer je deloval drug (prezbiterijanski) pastor in še bolj revolucionaren inovator. V Edinburghu je leta 1699 James Kirkwood (c. 1650-1708) objavil anonimni Predlog (Overture) za vzpostavitev knjižnic v vsaki župniji. ${ }^{6}$ Gre za detajlni in ambiciozni načrt, $s$ katerim bi bile pastorjeve zasebne knjige jedro vsake knjižnice. Župnijski učitelj bi služil kot knjižničar, vzpostavil pa bi še uniformni sistem katalogizacije. Predlagana shema je vključevala centralni urad s svojo založniško hišo, da bi izdajali poceni izdaje standardnih del, in poseben knjižnični davek za vsako župnijo. Po njegovih smernicah bi morale biti knjižnice na suhem, knjige pa pod ključem. Nekatere bi se lahko sposodilo, a vsakemu bralcu največ dve naenkrat. Vsaka knjiga je morala imeti ceno v katalogu, da je lahko bralec ob izposoji predal četrtino več vrednosti knjige kot depozit ("varovalka« za njeno varno vrnitev) (Kirkwood, An Overture).

Predlog so sicer sprejeli, a ga iz praktičnih razlogov niso izvajali. Tako je 1702 objavil še en traktat, a tokrat bolj geografsko ciljno, da

${ }^{6}$ Beseda overture je v tem kontekstu terminus technicus za predlog, naslovljen na star škotski parlament oziroma Vrhovno skupščino škotske cerkve. 
bi vzpostavili knjižnice po višavju (Highlands), kjer knjižnic praktično ni bilo. Ta predlog so sprejeli bolje in ga delno izvedli. Med drugim je prezbiterijanske Škote prepričeval, da morajo, če želijo spreobrniti heretične Angleže, najprej poznati njihova dela (Kirkwood, A Copy). Kirkwood je vzpostavil 77 župnijskih knjižnic. Ker je leta 1709 umrl, se njegova shema ni razvila, vzpostavljene knjižnice pa so postopoma propadle (Kelly, Early). Stranski produkt delovanja Braya in Kirkwooda je bil leta 1709 sprejeti odlok za ohranitev župnijskih knjižnic, ki je prvi neposredni primer knjižnične zakonodaje v Veliki Britaniji. Po tem zakonu se je župnija zavezala, da bo ohranila knjižnico, ki jo je prejela. Kljub temu odloku so župnijske knjižnice propadale.

Najbolj znamenita mestna knjižnica je Chethamova knjižnica v Manchestru, ki so jo opisali kot "najstarejšo še delujočo javno knjižnico v angleško govorečem svetu« (Nicholls 20). Ustanovljena je bila leta 1653, ko je premožni trgovec Humphrey Chetham v oporoki zapustil denar za postavitev knjižnice $v$ prosto "uporabo učenjakom in drugim«. Chethamova knjižnica je imela omejen odpiralni čas, bila je referenčna, povprečno pa jo je uporabljalo le 25 oseb na dan. Kljub temu so jo še sredi 19. stol. izpostavljali kot vzorčni primer dostopnosti knjižnice, ki bi naj bila edina v Angliji primerljiva s tistimi na kontinentu (Ewart Report iv-vi).

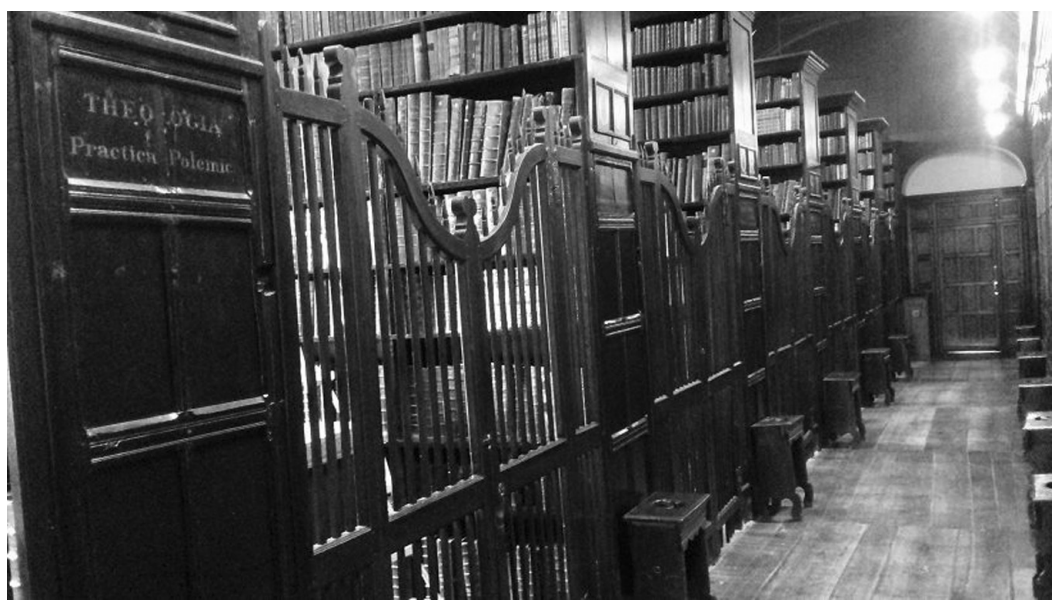

Slika 5: Notranjost Chethamove knjižnice v Manchestru (Foto Izidor Janžekovič 2017). Vrata do polic so postavili okrog leta 1745 , ko so začeli opuščati pritrjevanje knjig z verigami, a so še vedno želeli preprečiti direkten stik bralca s knjižnimi policami. Knjižnica še danes deluje kot referenčna knjižnica. Med drugim sta tukaj Karl Marx in Friedrich Engels v 1840-ih pisala Komunistični manifest. Engels je v pismu Marxu 24 let kasneje nostalgično opisoval čas, ki sta ga »skupaj preživela v tisti niši«. Niša, v kateri sta sedela, je gledala neposredno na delavce v pristanišču. 
Knjižnica in pripadajoča šola sta stali v Chethamovem dvorcu Clayton Hall ter sta bili pod kontrolo neodvisnega odbora skrbnikov (feoffees). Leta 1791 bi naj glede na prva dva zvezka kataloga imela 6723 knjig (Radcliffe). Katalog je bil napisan v latinščini in je skupno do leta 1883 izšel $\mathrm{v}$ šestih zvezkih, pri čemer je knjige $\mathrm{v}$ prvih zvezkih navajal le po velikosti in temah. Matthew Yeo se je v svoji disertaciji posvetil nabavam knjig pred letom 1700 glede na akcesijske registre, zato današnji digitalni katalog Chethamove knjižnice za najstarejše nabave vsebuje tudi ta podatek (Yeo).

Knjižnice s članarino iz 18. stoletja povzročajo največ težav pri klasifikaciji. Stroški se namreč razdelijo med člane skozi sistem rednih (mesečnih ali letnih) članarin, naročnin ali vpisnin, a se tukaj težave šele začnejo. $V$ tem času so se namreč izrazi javna knjižnica (public library), knjižni klub (book club), družbena knjižnica (community library), knjižnica s članarino (subscription library), izsposojevalna knjižnica (circulating library) ${ }^{7}$ in potujoča knjižnica (itinerary library) prekrivali, sovpadali in uporabljali v različnih pomenih (Kelly, Early 241243; Kaufman, "Community Lending Libraries«; "The Community Library«). Te zbirke so bile načeloma majhne, redko preko nekaj tisoč knjig, zato so tudi redke knjižnice s članarino imele svoje zgradbe.

Knjižni klub je bila majhna družba prijateljev in somišljenikov $s$ skupnim fondom za nakup knjig. Člani so bili večinoma izobraženi meščani, knjige pa so bile resne s prevladujočo politično periodiko in pamfleti. Članstvo je bilo omejeno, izstopajoč je bil družabni element. Mesečni sestanek, ki so ga imeli za izbor in izmenjavo knjig (običajno ob polni luni, da je bilo potovanje do sestanka lažje), je bil družabna priložnost, ki so jo pospremili s pitjem in večerjo. Čeprav so bili knjižni klubi v mestih, je bila njihova prednost, da so uspevali tudi v manjših skupnostih, kjer bi bilo težko postaviti stalno zbirko (Kaufman, "English Book Clubs«; Kelly, Early 136-143). Meščanski knjižni klubi niso imeli stalnih zbirk, zato niso potrebovali ne knjižnic ne knjižničarja.

Zasebne knjižnice s članarino so pravzaprav zrasle iz knjižnih klubov. Člani so prav tako plačali članarino za včlanitev v knjižnico, nato pa še vsakoletni prispevek. Ključna razlika s knjižnim klubom je bila, da se vsi člani niso nujno poznali, ampak so imele zasebne knjižnice s članarino širši domet, prav tako pa so določili posebno sobo ali stavbo za hrambo knjig. Knjižnice je vodil izvoljeni odbor (committee), ki je sprejel knjižnična pravila. Ko so sčasoma nastavili plačanega knjižničarja,

${ }^{7}$ Cf. Brayjev izraz za župnijske "izposojevalne knjižnice» (lending libraries), ki pa niso bile komercialno usmerjene. 
je bil služabnik odbora. Brali so resno literaturo in časopisje, leposlovje se je pojavilo tekom 18. stoletja, podobno kot drugod (Kelly, Early 121-135).

Prva zasebna knjižnica s članarino v Angliji je nastala v Liverpoolu. Meščani so se zbirali in diskutirali o literarnih temah $\mathrm{v}$ hiši Williama Everarda, zato so v začetku 1758 oblikovali zasebno knjižnico s članarino (Lyceum) (prim. Catalogue of the Liverpool Library). Katalogi so pogosto vsebovali tudi osnovna pravila knjižnice, strukturo, vodstvo, celo račune itd. V naslednjih 50 letih so vzpostavili knjižnice s članarinami v večini večjih mest, med drugimi sta $v$ Londonu nastali dve javni knjižnici, London Society Library iz leta 1785 in Westminster Public Library iz leta 1789 (Kaufman, »The Eighteenth-Century«; Manley, »The London«137-159).

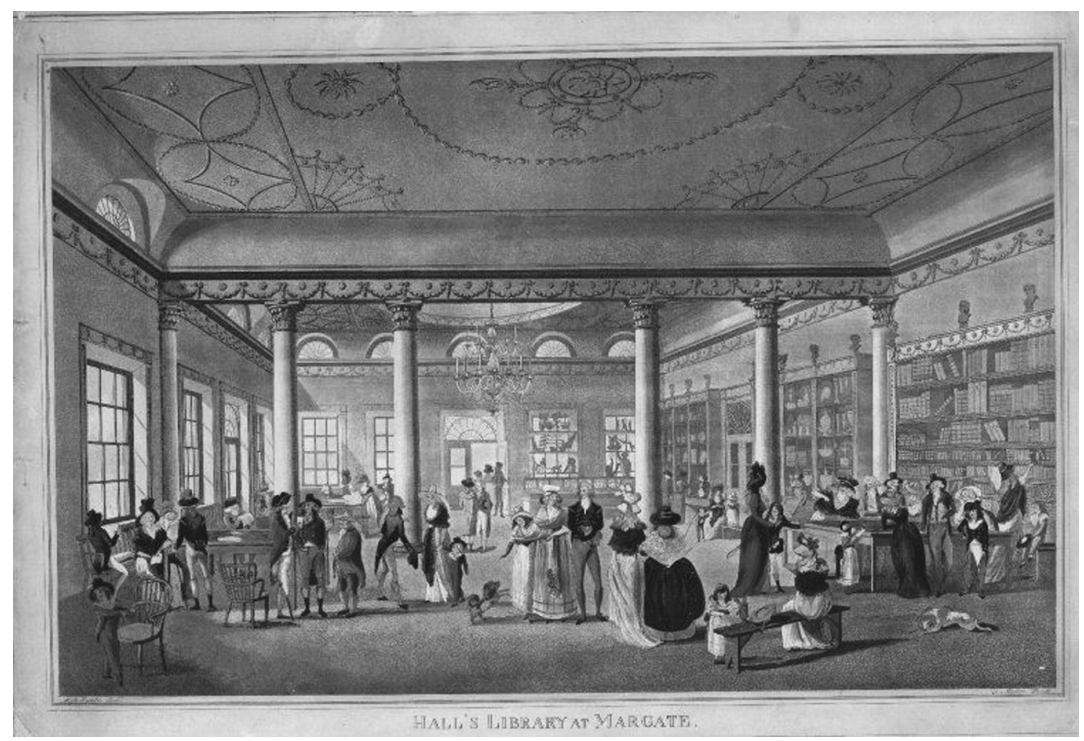

Slika 6: Hallova izposojevalna knjižnica v letoviškem mestu Margate na skrajnem JV Anglije okrog leta 1789. Slika polna ljudi (in živali) lepo prikaže precej bolj živahno naravo teh knjižnic v primerjavi z današnjimi, saj so bile takrat predvsem družabne in komercialne ustanove.

Izposojevalne knjižnice imajo dolgo tradicijo, saj so v Londonu komercialni kopisti že v 15. stoletju dajali v najem rokopise. Od reformacije naprej je bilo za prodajalce običajno, da so za plačilo posojali viške knjig. Toda izposojevalna knjižnica kot posebna oblika knjižnice spada v 18. stoletje in njihovo rast je nedvomno spodbudila rastoča priljublje- 
nost romana. Začelo naj bi se okrog 1726, ko je Allan Ramsay (16861758), pesnik, prodajalec knjig in lasuljar, ustvaril ločeno zbirko knjig za posojo v Edinburghu (The Athenaeum Journal 295, 877; Manley, "Scottish«). Do 1750-ih let so bile izposojevalne knjižnice v Londonu in vseh večjih mestih, leta 1801 naj bi jih bilo v VB že več kot 1000 . Edward Edwards se je zavedal njihovega obstoja, a presenetljivo o njih ni pisal, čeprav je bil celo sam član ene takih knjižnic: Mudie's Select Library (Catalogue of New; prim. Roberts).

Odnos elitne izobražene javnosti je bil precej sovražen do izposojevalnih knjižnic. To je bila tema številnih vročih debat tudi ob vzpostavitvi pravih javnih knjižnic sredi 19. stoletja, ker bi se naj usmerile le na "popularno" oziroma "nizko« literaturo. To je ustvarilo nov razred bralcev, posebej žensk, kar je do določene mere razburilo družbo. Prodajalec knjig James Lackington je recimo leta 1791 rekel: »Izposojevalne knjižnice so veliko prispevale $\mathrm{k}$ zabavi in kultivaciji drugega spola; kar največji delež dam ima zdaj okus za knjige" (Lackington 247). Predsodek, da so te knjižnice imele samo »lahko « leposlovje (popular fiction), ne drži v celoti. Knjižnice so namreč imele široko ponudbo, kot izdajo katalogi izposojevalnih knjižnic. Veliko izposojevalnih knjižnic je kombiniralo izposojo knjig s prodajo sladic, kave, pisarniške opreme, parfumov in zdravil (Kelly, Early 143-149; slika 6). Knjižnice so podobno kot danes organizirale številna poljudna predavanja in zabavne dogodke.

Prave potujoče knjižnice (itinerating libraries) si je zamislil trgovec Samuel Brown (1779-1839) na Škotskem. Premožni posamezniki, kot sta kralj Henrik VIII. v 16. in William Hakewill v 17. stoletju, so že prej potovali s svojimi knjižnicami in jih dali na voljo svojim prijateljem. Brown je vedel, da mala "statična knjižnica» kmalu preživi svoj namen in zaloga postane neuporabna, kar je bila običajna slabost župnijskih in mestnih knjižnic (Brown). Brown je od 1817 vzpostavil več manjših knjižnic z različno zalogo (okvirno 50 naslovov vsaka), ki jih je menjaval na dve leti, da je bila zaloga "sveža«; do leta 1836 je krožilo oziroma potovalo 47 knjižnic. Odločen je bil, da bo sponzoriral izobraževalne knjižnice v oddaljenih in izoliranih krajih. Tako je ocenjeval, kako bi z malo denarja naredil največ koristi. Brown je svojo shemo potujočih knjižnic razširil še v Anglijo, Irsko, Rusijo, Južno Afriko, na Karibe, itd. Večina naslovov v zalogi je odsevala Brownov okus ali svetovni nazor, in sicer je imel večinoma religiozne oziroma moralne knjige, preostanek pa je posvetil potopisom, znanosti, umetnosti in poljedelstvu (Passet 315-316). 


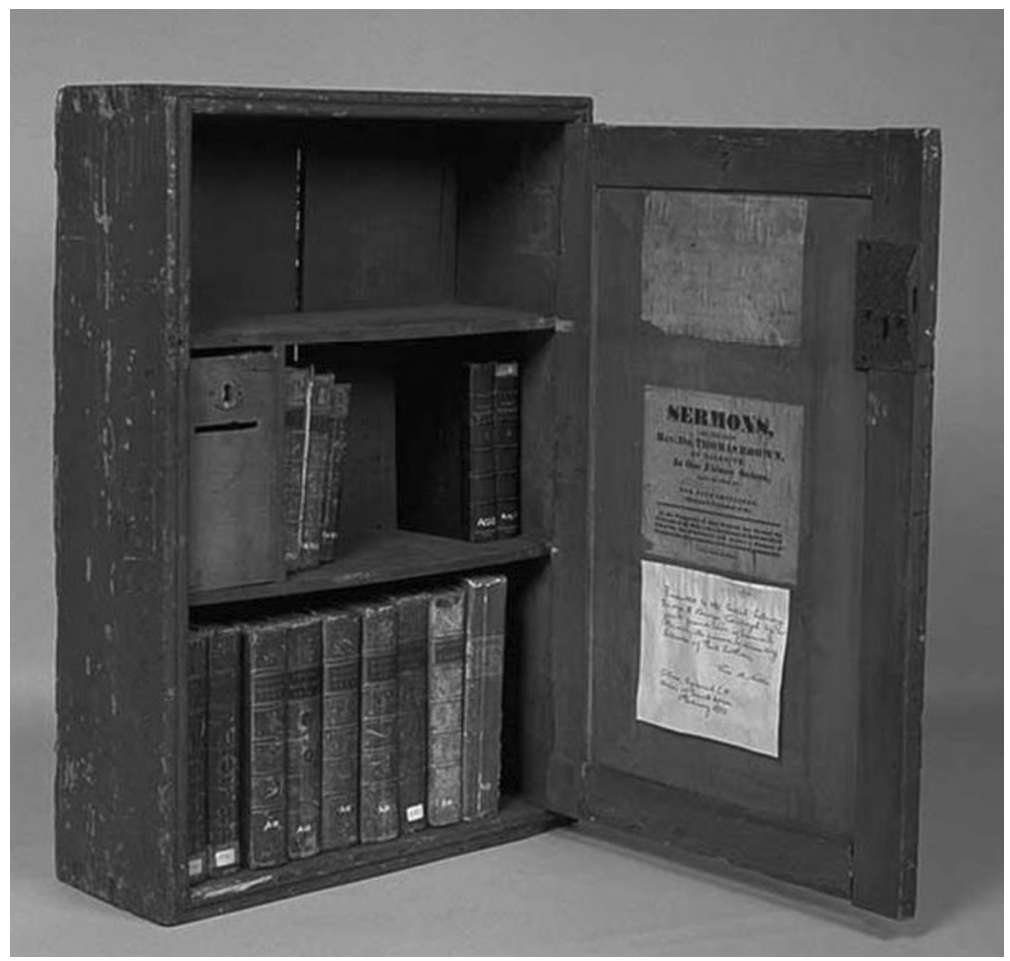

Slika 7: Brownova "potujoča knjižnica« oziroma škatla s knjigami. Razdeljena je bila na tri police, na srednji je bil tudi predalček za novce, na vratih pa so bila prilepljena obvestila o pridigah in aktualnih dogodkih.

\section{Zaključek}

Hkrati s pismenostjo se je večala potreba in želja ljudi po branju, posledično pa po vedno večji dostopnosti do knjig in knjižnic. Prve javne knjižnice niso nastopile šele $s$ pojavitvijo odprtih in izposojevalnih knjižnic sredi 19. stoletja, ampak je zainteresirana javnost imela dostop do knjižnih zbirk že v zgodnjem novem veku, čeprav $\mathrm{v}$ tistem času večinoma referenčnih knjižnic. Knjižnice so v Angliji namreč praviloma vse do konca 17. stoletja imele knjige pritrjene $\mathrm{z}$ verigami, manj brane knjige pa so hranili celo v skrinjah. Knjižnice so nastale ali se večale predvsem $\mathrm{z}$ darovi bogatih pokroviteljev. Knjige so bile sprva večinsko teološke narave, a je bilo vedno več zgodovinskih, potopisnih, naravoslovnih, od 18. stoletja postopoma začne prevladovati leposlovje. 
Pri razvoju in pomenu književnosti je svežo teorijo ponudila kulturna zgodovinarka Lynn Hunt. $Z$ razvojem pisemskega romana in druge "popularne" literature v Franciji in Angliji v drugi polovici 18. stoletja so se začele razvijati tudi univerzalne človekove pravice. Hunt namreč trdi, da so človekove pravice odvisne od naše sposobnosti vživetja in sočutja oziroma empatije $s$ tujci (Hunt), kar je ena bistvenih funkcij (sentimentalnih) romanov, ki so bili posebej priljubljeni v izposojevalnih knjižnicah v 18. stoletju. To se odraža v raznih deklaracijah, med njimi je gotovo najbolj znana Deklaracija o pravicah cloveka in državljana iz leta 1789, in človekoljubnih gibanjih, kot je bil abolicionizem za odpravo suženjstva. Skozi tisk ali tiskarski kapitalizem se po Benedictu Andersonu oblikuje oziroma utrdi občutek pripadnosti skupnosti (Anderson), tako lokalne in nacionalne kot globalne in univerzalne.

Pomemben način za pridobivanje knjig $\mathrm{v}$ institucionalnih knjižnicah je v zgodnjem novem veku postal zakon obveznega izvoda. Ta se je najprej pojavil v Franciji konec leta 1537 s predpisom Franca I. (Ordonnance de Montpellier), ki bi naj obogatil kraljevo knjižnico. Podobne ukrepe so nato sprejeli tudi v drugih državah. V Angliji je bil pred uradnim zakonom sprejet ustni dogovor leta 1610 med Thomasom Bodleyjem in Papirniško družbo (Stationers' Company). Z odlokom Star Chamber leta 1637 je postal izvod za knjižnico Bodleian obvezen, a 1640 je bil ta odlok razveljavljen in je spet postal prostovoljen (Crews).

Z uradno uzakonitvijo zakona o obveznem izvodu so bile vanj vključene tako Kraljeva knjižnica kot univerzitetni knjižnici v Cambridgu in Oxfordu. Glavni namen teh odlokov ni bil, da bi pomagali knjižnicam, ampak cenzura, da bi pravočasno opazili bogokletno in uporniško literaturo. Kasneje so se založniki zavezali, da bodo obvezni izvod poslali na kar devet naslovov: poleg teh treh knjižnic še kolidžu Sion v Londonu, pravni knjižnici v Edinburghu in štirim škotskim univerzam (Copyright $A c t$ ). Danes ima večina držav v veljavi zakon o obveznem izvodu, ki običajno roma v nacionalne knjižnice.

Zelo težko je natančno razmejiti med zasebno in javno sfero v zgodnjem novem veku (Habermas; Condren; Lake in Pincus). Dostop javnosti, ki so ga knjižnice tedaj dopuščale, je bil zelo raznolik. Institucionalne knjižnice so bile najprej namenjene članom institucije, a nekatere so bile prosto dostopne za zainteresirane zunanje obiskovalce. Dostop do podarjenih knjižnic je bil odvisen od pogojev vzpostavitve, pri čemer so lahko bile namenjene le župniku ali pa vsem župljanom. Knjižnice s članarino so bile redko dostopne za nečlane, 
zato je bila dostopnost odvisna od velikosti članarin: nekatere so bile zaradi visokih članarin zelo ekskluzivne, druge zaradi nizkih članarin relativno dostopne. Slednje so se tudi bolj odzivale na želje bralcev, saj so za preživetje morale zajeti karseda raznolike javne želje, da bi čim večji del javnosti privabile v knjižnice. Pri tem pa je še danes živa debata o standardu knjižnic in knjig, ki jih hranijo.

\section{VIRI}

Bacon, Francis. The Works of Francis Bacon. Vol. X. London: Longmans and Co., 1865. Bertius, Pierre. Nomenclator autorum omnium, etc. Leiden: F. Raphelengius, 1595.

Bray, Thomas. An Essay Towards Promoting All Necessary and Useful Knowledge, Both Divine and Human, in All the Parts of His Majesty's Dominions, Both at Home and Abroad. London: E. Holt, 1697.

Bray, Thomas. Bibliotheca Parochialis. Or, a Scheme of such Heads both General and Particular as are More peculiarly Requisite to be well Studied by every Pastor of a Parish. London: Robert Clavel, 1698.

Bray, Thomas. Proposals For the Incouragement and Promoting of Religion and Learning in the Foreign Plantations. And to Induce such of the Clergy of this Kingdom, as are Persons of Sobriety and Abilities, to accept of a Mission into those Parts. London: Thomas Lawrence, 1701.

Bray, Thomas. Bibliothecae Americanae Quadripartitae viz: I. Generales, Sive Bibliotheca Regia Annopolitana; II. Provinciales; III. Decanales; IV. Parochiales, or Catalogues of the Libraries sent into the Severall Provinces of America. London: MS at Sion College, 1702.

Bray, Thomas. Brief Account of the Life. London: W. Roberts, 1728.

Brown, Samuel. Some Account of Itinerating Libraries and Their Founder. Edinburgh: W. Blackwood and Sons, 1856.

Buckingham, James. Evidence on Drunkenness, Presented to the House of Commons, by the Select Committee Appointed by the House to Inquire into this Subject, and Report the Minutes of Evidence, with their Opinions thereupon. London: D. Martin, 1834.

Bury, Richard de. Philobiblon. Oxford: Basil Blackwell, 1970.

Carley, J. P., ur. John Leland: De viris illustribus. Toronto; Oxford: Pontifical Institute of Mediaeval Studies, Bodleian, 2010.

Catalogue of new and standard works in circulation at Mudie's Select Library. London: Mudie's, 1860.

Catalogue of the Liverpool Library. At the Lyceum, Bold-Street. Liverpool: James Smith, 1814.

Copyright Act: 8 Ann. c. 21. London: House of Commons, 1710.

Credland, William Robert. The Manchester Public Free Libraries. A History and Description, and Guide to Their Contents and Use. Manchester: Public Free Libraries Committee, 1899.

Edwards, Edward. "A Statistical View of the Principal Public Libraries in Europe and the United States of North America". Journal of the Statistical Society of London 11.3 (1848): 250-281.

Edwards, Edward. Memoirs of Libraries. 2 zv. London: Trübner and Co., 1859. 
Edwards, Edward. Three Reports on the Origin, Formation, and First Year's Working of the Manchester Free Library with an Introduction on the results and the defects of the Public Libraries Act of 1850. Manchester: Manchester Free Library, 1853.

Ewart Report. Reports from the Select Committee on Public Libraries. London: Hansard, 1849.

Fuller, Thomas. The Church-History of Britain from the birth of Jesus Christ until the year M.DC.XLVIII. London: John Williams, 1655.

Greenwood, Thomas. Free Public Libraries. Their Organisation, Uses, and Management. London: Simpkin, Marshall \& Company, 1886.

Hansard, T. C. Hansard's Parliamentary Debates, Vol. XXX. London: Baldwin and Craddock et al., 1835.

Illustrated London News. London, 11. september 1852.

James, Thomas. Catalogus librorum bibliothecae publicae. Oxford: Josephus Barnesius, 1605.

James, Thomas. Catalogus universalis librorum in bibliotheca Bodleiana. Oxford: Johannes Lichfield \& Jacobus Short, 1620.

Johnson, Samuel. A Dictionary of the English Language. London: J. \& P. Knapton et al., 1755.

Kanič, Ivan. Angleško-slovenski slovar bibliotekarske terminologije. Ljubljana: Narodna in univerzitetna knjižnica, 2002.

Kirkwood, James. An Overture for Establishing of Bibliothecks in Every Paroch Throughout this Kingdom. Edinburgh: James Kirkwood, 1699.

Kirkwood, James. A Copy of a Letter Anent a Project for Erecting a Library in every Presbytery, or at least every County in the Highlands. Edinburgh: George Mosman, 1702.

Lackington, James. Memoirs of the Forty-Five First Years of the Life of James Lackington, Bookseller. London: Hunt \& Clarke, 1830.

Leland, John. New Year's Gift. London: John Bale, 1549.

Loggan, David. Oxonia Ilustrata. Bibbliotheca Bodleianae Oxoniae Prospectus Interior ab Occident. Oxford: Robert White, 1675.

Ordonnance de Montpellier 1539: Ampliation sur les ordonnances de la police de la ville de Paris necessaire de sçavoir a tous manans et habitans de ladicte ville. Publie a son de trompes, le septiesme jour de febvrier l'an mil cinq cens trente neuf. Paris: Jacques Nyverd, 1540.

Public Libraries Act: 13 \& 14 Vict., c. 65. London: House of Commons, 1850.

Radcliffe, John, ur. Bibliotheca Chethamensis, sive, Bibliothecae Publicae Mancuniensis ab Humfredo Chetham armigero fundatae catalogi. Manchester: J. Harrop, 1791.

Report of Her Majesty's Commissioners. London: House of Commons, 1854-55.

The Athenaeum Journal of Literature, Science, and the Fine Arts, for the Year 1849. London: James Holmes, 1849.

Wood, Anthony. The History and Antiquities of the University of Oxford. Oxford: Oxford University Press, 1674.

Wood, Anthony. Athenae Oxonienses. An Exact History of All the Writers and Bishops Who have had their Education in the University of Oxford. London: P. C. and J. Bivington et al., 1813. 


\section{LITERATURA}

Anderson, Benedict. Zamišljene skupnosti. O izvoru in širjenju nacionalizma. Ljubljana: Studia humanitatis, 2007.

Brown-Syed, Christopher. "The Love of Books: The Philobiblon of Richard De Bury«. Library \& Archival Security 19 (2004): 76-81.

Carpenter, Michael. "Catalogs and Cataloging". Encyclopedia of Library History. Ur. Wayne A. Wiegand in Donald G. Davis. New York, NY; London: Garland Publishing, Inc., 1994. 107-117.

Casson, Lionel. Libraries in the Ancient World. New Haven, CT: Yale University Press, 2002.

Chandler, John H., ur. John Leland's Itinerary. Travels in Tudor England. Stroud: Sutton Publishing Ltd., 1998.

Chartier, Roger, ur. A History of Private Life III. Passions of the Renaissance. Prev. A. Goldhammer. Cambridge, MA; London: Belknap Press, 1989.

Clapinson, Mary. A Brief History of the Bodleian Library. Oxford: Oxford University Press, 2015.

Condren, Conal. »Public Private and the Idea of the 'Public Sphere' in Early-Modern England «. Intellectual History Review 19 (2009): 15-28.

Craster, Edmund H. History of the Bodleian Library. Oxford: Clarendon Press, 1952.

Cressy, David. »Levels of Illiteracy in England, 1530-1730«. The Historical Journal 20.1 (1977): 1-23.

Crews, Kenneth D. "Legal Deposit in Four Countries: Laws and Library Services«. American Association of Law Libraries 80 (1988): 551-576.

Cunningham, Hugh. Time, Work and Leisure. Life Changes in England since 1700. Manchester: Manchester University Press, 2014.

Eco, Umberto. Ime rože. Ljubljana: Mladinska knjiga; Delo, 2004.

Eberhart, George. The Librarian's Book of Lists. Chicago, IL: American Library Association, 2010.

Fehrenbach, Robert J. Private Libraries in Renaissance England. Binghamton, NY: Medieval \& Renaissance Texts \& Studies, 1992.

Fox, Peter, ur. Cambridge University Library. The Great Collections. Cambridge: Cambridge University Press, 1998.

Habermas, Jürgen. Strukturwandel der Öffentlichkeit. Untersuchungen zu einer Kategorie der bürgerlichen Gesellschaft. Neuwied; Berlin: Luchterhand, 1962.

Hamby, Paul, in Ira Najowitz. »The Public Libraries Act of 1850: Utilitarian Pragmatism and Idealist Humanitarianism in Action«. Public \& Access Services Quarterly 2.4 (1999): 73-88.

Hareven, Tamara K. »Family Time and Historical Time«. Daedalus 106.2 (1977): 57-70.

Hunt, Lynn. Iznajdevanje človekovih pravic. Zgodovina. Ljubljana: Znanstvena založba Filozofske fakultete, 2015.

Irwin, Raymond. Heritage of the English Library. London: George Allen \& Unwin, 1964.

Irwin, Raymond. The English Library. London: George Allen \& Unwin, 1966.

Jayne, Sears. Library Catalogues of the English Renaissance. Berkeley, CA: University of California Press, 1956.

Johnson, Alex. Improbable Libraries. A Visual Journey to the World's Most Unusual Libraries. Chicago: University of Chicago Press, 2015. 
Kaufman, Paul. "The Eighteenth-Century Forerunner of the London Library«. The Papers of the Bibliographical Society of America 54 (1960): 89-100.

Kaufman, Paul. "Community Lending Libraries in Eighteenth-Century Ireland and Wales". The Library Quarterly. Information, Community, Policy 33.4 (1963): 299-312.

Kaufman, Paul. "Reading Vogues at English Cathedral Libraries of the Eighteenth Century". Bulletin of the N. Y. Public Library 67 (1963): 643-672 (Part I); 68 (1964): 48-64 (Part II).

Kaufman, Paul. "English Book Clubs and Their Role in Social History". Libri 14 (1964): 1-31.

Kaufman, Paul. "The Community Library: A Chapter in English Social History". Transactions of the American Philosophical Society 57.7 (1967): 1-62.

Kelly, Thomas. Early Public Libraries. A History of Public Libraries in Great Britain before 1850. London: Library Association, 1966.

Kelly, Thomas. Books for the people. An illustrated history of the British public library. London: Andre Deutsch, 1977.

Lake, Peter, in Steve Pincus. "Rethinking the Public Sphere in Early Modern England «. Journal of British Studies 45.2 (2006): 270-292.

Manley, K. A. "The London and Westminster Libraries, 1785-1823«. The Library 6 (1985): 137-159.

Manley, K. A. "Scottish Circulating and Subscription Libraries as Community Libraries". Library History 19.3 (2003): 185-194.

McCulloch, Samuel C. »The Importance of Dr. Thomas Bray's Bibliotheca Parochialis«. Historical Magazine of the Protestant Episcopal Church 15.1 (1946): 50-59.

McLuhan, Marshall. The Gutenberg Galaxy. The Making of Typographic Man. Toronto: University of Toronto Press, 1962.

McMenemy, David. The Public Library. London: Facet Publishing, 2009.

Minto, John. A History of the Public Library Movement in Great Britain and Ireland. London: G. Allen \& Unwin, 1932.

Molino, Paola. "World Bibliographies: Libraries and the Reorganization of Knowledge in Late Renaissance Europe«. Canonical Texts and Scholarly Practices. A Global Comparative Approach. Ur. Anthony Grafton in Glenn W. Most. Cambridge: Cambridge University Press, 2016. 299-322.

Moretti, Franco. »Conjectures on World Literature". New Left Review 1 (2000): 54-68.

Munford, William A. Edward Edwards. Portrait of a Librarian, 1812-1886. London: Library Association, 1963.

Myers, Robin, in Michael Harris, ur. Stationers' Company and the Book Trade 15501990. Winchester: St Paul's Bibliographies, 1997.

Nethersole, Reingard. "World Literature and the Library«. The Routledge Companion to World Literature. Ur. Theo D'haen, David Damrosch in Djelal Kadir. New York, NY: Routledge, 2012. 307-315.

Neuhofer, Dorothy M. In the Benedictine Tradition. The Origins and Early Development of Two College Libraries. Lanham, MD: University Press of America, 1999.

Nicholls, Robert. Curiosities of Greater Manchester. Stroud: Sutton Publishing, 2004.

Norris, Dorothy M. A History of Cataloguing and Cataloguing Methods 1100-1850. With an Introductory Survey of Ancient Times. London: Grafton \& Company, 1939.

Oates, John C. T. Cambridge University Library. A History from the Beginnings to the Copyright Act of Queen Anne. Cambridge: Cambridge University Press, 1986.

Passet, Joanne E. "Historiography of Library History«. Encyclopaedia of Library History. New York, NY; London: Garland Publishing, 1994. 260-262. 
Piesse, A. J., ur. Sixteenth-Century Identities. Manchester: Manchester University Press, 2001.

Putnam, George H. Books and their Makers during the Middle Ages. New York, NY; London: G. P. Putnam, 1897.

Roberts, Lewis. Trafficking in Literary Authority. Mudie's Select Library and the Commodification of the Victorian Novel. Cambridge: Cambridge University Press, 2006.

Saenger, Paul. "Silent Reading: Its Impact on Late Medieval Script and Society«. Viator 13 (1982): 367-414.

Shrank, Cathy. Writing the Nation in Reformation England 1530-1580. Oxford: Oxford University Press, 2004.

Steiner, Bernard C. "Rev. Thomas Bray and his American Libraries». The American Historical Review 2.1 (1896): 59-75.

Stephens, W. B. »Literacy in England, Scotland, and Wales, 1500-1900«. History of Education Quarterly 30.4 (1990): 545-571.

Stone, Lawrence. "Literacy and Education in England, 1640-1900«. Past and Present 42 (1969): 69-139.

Taylor, Simon, Matthew Whitfield in Susie Barson. The English Public Library 1850 1939. London: Historic England, 2016.

Velagić, Zoran. "Reading Aloud: Between Oral and Literate Communication«. Friars, Nobles and Burghers - Sermons, Images and Prints. Studies of Culture and Society in Early-Modern Europe, in Memoriam István György Tóth. Ur. Jaroslav Miller in László Kontler. Budimpešta: Central European University Press, 2010. 379-387.

Venkat Mani, Bala. »Bibliomigrantstvo: Knjižna zbirka in ustvarjanje svetovne literature«. Svetovne književnosti in obrobja. Ur. Marko Juvan. Ljubljana: ZRC SAZU, 2012. 41-58.

Vickers, Kenneth H. Humphrey, Duke of Gloucester. A Biography. London: A. Constable and Company, 1907.

Yeo, Matthew. The Acquisition of Books by Chetham's Library, 1655-1700. Leiden: Brill, 2011.

Youings, Joyce A. The Dissolution of the Monasteries. London: Allen and Unwin, 1971.

\section{The First "Public" Libraries in Great Britain}

Keywords: library history / public libraries / Great Britain / 16th-19th cent. / parish libraries / subscription libraries / circulating libraries

This article presents the first "public" libraries in Great Britain in the Early Modern Era (sixteenth-nineteenth centuries), before the first truly public libraries appeared in the mid-nineteenth century. Based on critical reading of primary sources and secondary literature, the various forms of libraries are presented and the development of public libraries in the early modern era is sketched. The analysis showed what access the public really had to these librar- 
ies, who used them, and what literature they read. Essentially, it was a matter of simultaneous development and mutual influence: it was neither accessible literature nor the public library that developed first, but their relationship was always mutually dependent and proportional. Although the first truly public libraries were the thing of the mid-nineteenth century, the interested public could access libraries in the Early Modern Era.

1.01 Izvirni znanstveni članek / Original scientific article UDK 021(410)"15/18"

DOI: https://doi.org/10.3986/pkn.v44.i2.09 